\title{
Peran Ganda Buruh Perempuan Peternakan Ayam Petelur dalam Institusi Keluarga
}

\author{
Satna Deswandari ${ }^{1}$, Yosafat Hermawan Trinugaha ${ }^{1}{ }^{*}$, Yuhastina $^{1}$
}

${ }^{1}$ Universitas Sebelas Maret, Indonesia

\author{
A R T I C L E I N F O \\ Article history: \\ Received 19 June 2021 \\ Accepted 03 November \\ 2021 \\ Available online 01 \\ December 2021 \\ Kata Kunci: \\ Buruh Perempuan; Peran \\ Ganda; Beban Kerja Ganda; \\ Konstruksi Sosial \\ Keywords: \\ Workwoman; Dual Role; \\ Double Burden; Social \\ Construction
}

\begin{abstract}
A B S T R A K
Penelitian ini bertujuan untuk mengambarkan peran dan beban kerja ganda serta mengetahui konstruksi sosial perempuan yang sudah berkeluarga terhadap pilihannya menjadi buruh perempuan di PT Rehobat. Kajian ini menggunakan pendekatan kualitatif jenis studi kasus. Lokasi penelitian adalah peternakan ayam petelur PT Rehobat berada di Kecamatan Limbangan, Kabupaten Kendal. Metode observasi, wawancara dan dokumentasi digunakan dalam pengambilan data. Validitas data dengan triangulasi sumber dan analisis data dengan analisis kualitatif model interaktif Miles dan Hubberman. Penelitian ini menjelaskan peran dan beban kerja ganda yang dimiliki buruh perempuan meliputi peran dalam keluarga, bekerja, dan lingkungan rumah atau masyarakat. Adapun hasil penelitian menunjukan bahwa ibu rumah tangga yang memutuskan bekerja menjadi buruh peternakan melalui tiga proses yaitu eksternalisasi, objektivasi, dan internalisasi di mana proses tersebut menunjukan konstruksi penerimaan terhadap buruh perempuan peternakan yang menjalankan peran ganda. Proses tersebut proses dialektika sesuai dengan teori Konstruksi Sosial Peter L. Berger dan Thomas Luckmann. Sebuah penerimaan yang sebenarnya secara tak langsung masih menggambarkan ketidaksetaraan gender.
\end{abstract}

\section{A B S T R A C T}

This study aims to describe the role and dual roles, double burden, and find out the social construction of women who are married to their choice to become female workers at PT Rehobat. This study uses a qualitative case study approach. The research location is PT Rehobat's laying hens farm located in Limbangan District, Kendal Regency. The methods of observation, interviews, and documentation were used in data collection. Data were analyzed by qualitative analysis of the Miles and Huberman interactive model. This study explains female workers' dual roles and double burden, including roles in the family, work, and home or community environment. The study results show that housewives who decide to be workers go through three processes: externalization, objectivation, and internalization, in which the process shows the construction of acceptance of female farmworkers who carry out dual roles. The process is dialectical following the theory of Social Construction of Peter L. Berger and Thomas Luckmann. An acceptance that indirectly still illustrates gender inequality.

\footnotetext{
* Corresponding author.

E-mail addresses: yosafathermawan@staff.uns.ac.id
} 


\section{Pendahuluan}

Dalam kehidupan masyarakat terdapat pembagian peran laki-laki dan perempuan dalam keluarga yang berdasarkan gender. Gender yang dikonstruksikan secara sosial telah mengakibatkan berbagai ketidak-setaraan antara perempuan dan laki-laki dalam masyarakat. Ketidaksetaraan tersebut pada akhirnya melahirkan ketidakadilan yang merugikan salah satu pihak, terutama perempuan. Ketidakadilan terhadap perempuan tersebut berupa tuntutantuntutan yang dilayangkan masyarakat kepada perempuan di luar kodrat perempuan itu sendiri.

Kodrat perempuan dalam pengertian esensial atau kodrati dapat dirumuskan sebagai fitrah biologis perempuan yang melekat dalam tubuhnya atau dalam keniscayaan kemampuan reproduksinya. Pengertian ini mengarah pada beberapa kualitas atau kemampuan perempuan seperti hamil, menstruasi atau haid, melahirkan dan menyusui, meninggal aspek-aspek lain sebagai di luar dari kodrat perempuan, dan secara sosial dikonstruksi karenanya terbuka terhadap perubahan (Kusuma, 2014).

Tuntutan-tuntutan yang dilayangkan masyarakat kepada perempuan di luar kodrat perempuan, salah satunya disebabkan oleh mitos turun temurun di masyarakat. Mitos pada masyarakat Jawa misalnya, perempuan (istri) adalah "kanca wingking", artinya perempuan adalah teman di belakang. Mempunyai makna jika di dalam rumah urusan perempuan adalah di sekitar dapur dan berbagai urusan pekerjaan rumah tangga lainnya. Ungkapan lain yang menguatkan mitos tersebut adalah "wong wadon nggone nang njobo" (perempuan tempatnya di dapur). Ungkapan ini seringkali digunakan sebagai alasan orang tua untuk tidak menyekolahkan anak perempuan tinggi-tinggi, karena pada akhirnya ketika mereka menikah hanya akan berada di dapur dan mengurus rumah tangga (Relawati, 2011).

Perkembangan pembangunan yang semakin pesat membuka kesempatan bagi perempuan yang ingin bekerja. Saat ini pekerja perempuan sudah semakin terlihat dengan jelas di berbagai bidang pekerjaan. Berdasarkan aspek ekonomi dalam keluarga, keterlibatan perempuan atau istri dalam ketenagakerjaan mempunyai arti tersendiri, baik sebagai individu, istri, ibu rumah tangga maupun sebagai anggota masyarakat. (Momuat, S. M., Rantung, V. V., Wangke, W. M., \& Ngangi, 2013)

Jumlah tenaga kerja perempuan di sektor pertambangan per Agustus 2017 tercatat sebanyak 115.063 orang (dibandingkan laki-laki 1,28 juta orang), untuk sektor listrik, air, dan gas sebanyak 46.449 orang (dibandingkan laki-laki 347,42 ribu orang), dan untuk sektor jasa keuangan sebesar 1.091.838 orang (dibandingkan laki-laki 2,66 juta orang). Di sisi lain, perempuan masih lebih banyak menyumbang tenaga kerja di sektor-sektor yang memiliki upah rata-rata bulanan yang relatif rendah, seperti perdagangan, restoran, dan hotel (Rp 2,26 juta/bulan), dan pertanian (Rp 1,77 juta/bulan) (Prakoswa, 2018).

Data tersebut menunjukkan jumlah tenaga kerja perempuan cukup tinggi, meskipun jumlah tersebut lebih sedikit daripada jumlah tenaga kerja laki-laki. Akan tetapi jumlah ini tetap membuktikan bahwa saat ini perempuan ikut berkontribusi dalam aspek ekonomi yaitu dengan bekerja.

Seorang perempuan yang sudah menikah atau istri yang bekerja menjalankan peran ganda sebagai ibu rumah tangga dan pekerja sekaligus memiliki beban kerja ganda. Beban kerja ganda adalah beban pekerjaan yang diterima salah satu jenis kelamin lebih banyak dibandingkan jenis kelamin lainnya. Peran perempuan di dalam rumah seringkali dipandang permanen. Akibatnya, ketika perempuan turut bekerja di luar rumah, ia masih dibebani tanggung jawab atas kegiatan di dalam rumah. Adanya perbedaan peran laki-laki dan perempuan serta peran ganda yang dialami oleh para perempuan yang bekerja, salah satunya disebabkan oleh konstruksi sosial yang berekembang di lingkungan masyarakat.

Hal ini serapa dalam penelitian tentang peran ganda buruh perempuan di Temanggung Jawa Tengah yang menjelaskan bahwasanya buruh perempuan pabrik kayu PT Albasia berperan ganda dengan menjalankan peran publik, peran domestik dan peran sosial dalam kehidupan mereka. Peran publik sebagai pekerja pabrik, peran domestik sebagai ibu rumah tangga dan peran sosial sebagai anggota masyarakat. Latar belakang buruh perempuan menjalankan peran ganda adalah faktor ekonomi dan faktor jarak dan lingkungan (Jannah, S.M., \& Lestari, 2007). 
Demikian juga yang dialami perempuan buruh pemetik teh yang berstatus menikah di Desa Keteleng, Kabupaten Batang di mana mereka harus bisa membagi waktu antara pekerjan domestik mereka sebagai ibu rumah dengan pekerjaan publik mereka sebagai buruh pemetik teh. Jika kondisi ini yang terjadi, maka tidak jarang peran ganda perempuan berubah menjadi beban ganda perempuan. Apalagi menurut dalam penelitiannya, sebagian besar budaya masyarakat Indonesia pada umumnya dan khususnya Jawa, memosisikan peran perempuan sebagai pemeran utama dalam rumah tangga, yaitu: melahirkan dan mengasuh anak, menyiapkan kebutuhan makanan, dan tata kelola ekonomi rumah tangga (Rosadi dalam Kusumawati, 2012).

Peran dan beban kerja ganda dialami pula oleh para perempuan yang bekerja sebagai buruh di peternakan ayam petelur PT Rehobat yang terletak di Kecamatan Limbangan, Kabupaten Kendal, Jawa Tengah. Mayoritas buruh perempuan tinggal di perdesaan dengan latar belakang ekonomi keluarga tergolong menengah ke bawah sehingga mereka bekerja agar kehidupan ekonomi keluarga menjadi lebih baik. Bekerja sebagai buruh peternakan ayam petelur tentu tidak mudah terutama untuk perempuan. Mereka harus membagi waktu dan menyiapkan stamina setiap harinya untuk mengerjakan pekerjaan rumah tangga dan bekerja, apalagi bekerja sebagai buruh peternakan ayam petelur mengutamakan tenaga fisik.

Berbeda dengan penelitian-penelitian sebelumnya, penelitian ini mencoba menggunakan prespektif teori konstruksi sosial oleh Peter L. Berger dan Thomas Luckmann untuk menguraikan konstruksi sosial perempuan yang sudah berkeluarga terhadap pilihannya menjadi buruh perempuan peternakan ayam petelur PT Rehobat. Selain menggunakan prespektif teori konstruksi sosial oleh Peter L. Berger dan Thomas Luckmann, implikasi teoritis dalam penelitian ini akan membahas mengenai peran perempuan khususnya buruh perempuan dengan konsep dualisme kultural, yakni adanya konsep ranah domestik (domestic sphere) dan ranah publik (public sphere). Sehingga perlu adanya penelitian ini agar dapat memberikan manfaat bagi para buruh perempuan untuk lebih memahami peran dan beban kerja ganda, kodrat perempuan dan konstruksi sosial perempuan yang sudah berkeluarga terhadap pilihannya menjadi buruh perempuan yang pada akhirnya mereka dapat menerima, bertangung jawab terhadap peranperan yang mereka miliki, serta mendukung pencapaian kesetaraan gender.

\section{Metode}

Pendekatan yang digunakan dalam penelitian ini adalah metode kualitatif dengan jenis studi kasus tunggal. Studi kasus tunggal terarah pada sasaran dengan satu karakteristik (Sutopo, 2002). Mengingat penelitian ini hanya dilakukan pada satu sasaran, satu objek yaitu para buruh perempuan peternakan ayam petelur PT Rehobat. Penelitian ini dilakukan di Peternakan Ayam PT. Rehobat di Desa Limbangan, Kecamatan Limbangan, Kabupaten Kendal, Jawa Tengah. Peternakan Ayam PT. Rehobat dipilih karena hampir 75\% pekerjanya adalah seorang buruh perempuan, baik berstus menikah maupun lajang. Penelitian ini berkaitan dengan peran ganda buruh perempuan dalam institusi keluarga, maka subyek penelitian dalam penelitian ini adalah para buruh perempuan Peternakan Ayam PT Rehobat yang berstatus menikah. Jumlah informan utama dalam penelitian ini adalah 10 orang dan informan pendukung berjumlah 3 orang.

Teknik pengumpulan data yang digunakan dalam penelitian ini adalah wawancara mendalam (in-depth-interview), observasi dan dokumentasi terkait dengan peran ganda buruh perempuan dalam institusi keluarga. Metode triangulasi digunakan untuk validasi data penelitian dengan sumber dengan cara cross check data yang diperoleh. Analisis data yang digunakan adalah analisis deskriptif dimaksudkan untuk memperoleh gambaran yang lebih jelas tentang keadaan yang sedang berlangsung dan lebih menekankan pada proses dan makna terkait dengan penelitian. Adapun terdapat empat langkah yang digunakan peneliti dalam menganalisis data, yang pertama proses pengumpulan data, yang kedua reduksi data dengan menggolongkan, mengarahkan, membuang data yang tidak perlu, dan mengorganisasikan data menurut hemat peneliti, yang ketiga penyajian data dengan menarasikan serta menyusun sedemikian rupa hasil wawancara dan observasi, serta yang terakhir adalah penarikan kesimpulan dengan mengambil inti atau makna dari sajian data yang telah tersusun. 


\section{Hasil dan Pembahasan}

Limbangan adalah sebuah kecamatan di Kabupaten Kendal, Jawa Tengah, Kecamatan Limbangan merupakan satu dari 20 kecamatan di Kabupaten Kendal Provinsi Jawa Tengah. Luas wilayah Kecamatan Limbangan mencapai $71,72 \mathrm{~km}^{2}$, yang sebagaian besar digunakan sebagai lahan hutan negara yaitu mencapai 38.99\%. Sedangkan lahan untuk tanah sawah sebesar 34.92\%, lahan untuk tanah sawah sebesar 17, 04\% dan sisanya sebesar 2,55\% digunakan untuk lain-lain.

Lokasi PT Rehobat yang terletak di Kecamatan Limbangan telah membuka peluang kerja bagi para penduduk Kecamatan Limbangan, baik laki-laki maupun perempuan yang saat ini jumlah total karyawan adalah 990 orang. Salah satu peluang kerja yang diberikan oleh PT Rehobat adalah sebagai buruh pengurus ayam atau disebut dengan operator kandang. Pekerjaan sebagai buruh pengurus ayam atau operator kandang ini tidak membutuhkan kualifikasi pendidikan maupun ketrampilan yang tinggi serta cocok untuk dikerjakan oleh perempuan. Sehingga, banyak perempuan sekitar, termasuk yang berstatus sebagai ibu rumah tangga memilih menjadi buruh peternakan ayam petelur di PT Rehobat ini.

PT Rehobat saat ini telah mempekerjakan para perempuan di daerah Kecamatan Limbangan sebagai buruh peternakan ayam petelur sebagai operator kandang. Salah satu alasannya adalah karena perempuan pada umumnya memiliki keterampilan dan kecermatan yang lebih dibandingkan dengan laki-laki, yang sangat diperlukan selama mengurus ayam, apalagi yang diurus adalah ayam sebagai mahkluk hidup.

Selain karena lokasinya yang cukup dekat, juga karena sebagaian besar para buruh yang bekerja di PT Rehobat ini mempunyai tingkat pendidikan dan keterampilan yang rendah. Hal ini dibuktikan, dari 10 informan utama buruh perempuan di peternakan ayam petelur PT. Rehobat, 1 diantarnya lulusan Sekolah Dasar (SD), 7 diantaranya lulusan Sekolah Menengah Pertama (SMP), dan 2 diantaranya lulusan Sekolah Menengah Atas (SMA). Tingkat pendidikan dan keterampilan yang rendah ini membuat mereka memiliki keterbatasan dalam pemilihan pekerjaaan.

Bagi para buruh perempuan yang bekerja di peternakan ayam petelur PT Rehobat ini, adanya PT Rehobat merupakan suatu berkah tersendiri bagi mereka karena telah memberikan kesempatan bagi para perempuan untuk bekerja dan mendapatkan gaji sesuai dengan UMR (Upah Minimum Regional) Kabupaten Kendal yang pada tahun 2021 ini senilai 2,3 juta. Selain itu gaji yang dihasilkan oleh para buruh perempuan peternakan ayam petelur PT Rehobat ini telah mampu untuk memenuhi keperluan sehari-hari dan meningkatkan derajat perekonomian si perempuan maupun keluarga yang bersangkutan.

Hal ini seperti yang diungkapkan oleh F (45 tahun) yang sudah bekerja selama 14 tahun sebagai buruh di PT Rehobat. Pada salah satu wawancara yang dilakukan pada Kamis, 15 Januari 2021, Fahmidah mengungkapkan sebagai berikut:

"Saya malah senang dan bangga kalau ada perempuan yang kerja, apalagi yang sudah berkeluarga punya suami punya anak. Karena bisa bantu-bantu perekonomian keluarga, bisa mandiri tidak hanya minta-minta suami terus, istilahnya tidak njagakke (bergantung) suami gitu, saya juga bersyukur dan sangat berterimakasih, ada PT Rehobat ini yang buka lowongan kerja bagi para perempuan di sekitar sini, karena banyak peempuan disini yang hanya lulusan SD sama SMP jadi agak susah kalau cari kerja yang penghasilannya tetap dan ikut UMR, ya perempuan-perempuan yang lain di desa ini kalau ngak kerja di rehobat ya palingan jadi buruh tani atau buka warung atau jualan-jualan gitu."

Dengan masuknya perempuan, terutama yang berstatus sudah menikah, ke dalam pekerjaanpekerjaan sektor publik, maka perempuan kemudian menjalankan peran ganda, yaitu tidak hanya peran domestik sebagai ibu rumah tangga, namun juga sebagai peran publik, yaitu sebagai seseorang yang mencari nafkah (Supartiningsih, 2013). Hal ini juga sejalan dengan apa yang dikatakan oleh (Lantara, 2015) yang mengatakan bahwa perempuan memiliki tanggung jawab 
yang lebih berat dibandingkan laki-laki, karena harus bertanggungjawab di rumah dan di luar rumah.

\section{Peran dan beban kerja ganda buruh perempuan peternakan ayam petelur PT Rehobat}

Kodrat perempuan dalam pengertian esensial atau kodrati dapat dirumuskan sebagai fitrah biologis perempuan yang melekat dalam tubuhnya atau dalam keniscayaan kemampuan reproduksinya. Pengertian ini mengarah pada beberapa kualitas atau kemampuan perempuan seperti hamil, menstruasi atau haid, melahirkan dan menyusui, meninggal dan aspek-aspek lain sebagai di luar dari kodrat perempuan, dan secara sosial dikonstruksi karenanya terbuka terhadap perubahan (Kusuma, 2014).

Berdasarkan hal tersebut, peran dan beban kerja ganda yang dialami oleh para perempuan yang sudah menikah dan kemudian memutuskan untuk bekerja bukanlah merupakan kodrat seorang perempuan. Hal tersebut muncul karena adanya konstruksi sosial yang diciptakan oleh masyarakat. Konstruksi sosial tersebut telah menghasilkan konsep bahwa tugas seorang perempuan yang sudah menikah adalah menjadi ibu bagi anak dan istri bagi suami. Terlepas dari peran-peran serta tugas pekerjaan rumah tangga atau domestik. Seorang ibu juga bertanggung jawab terhadap pengasuhan dan kehidupan anaknya. Seperti yang diungkapkan oleh Brazelton, peranan wanita yang paling penting adalah tinggal di dalam rumah, dan menjadi ibu bagi anakanaknya. Stigma atau pandangan seperti ini sudah menjadi tradisi dalam kebanyakan kehidupan masyarakat, sebab peran ibu yang utama adalah mengurusi rumah tangga serta mengasuh anak. Selain itu, peran seorang istri atau ibu juga sangat sentral atau utama dalam mengatur ekonomi keluarga atau merencanakan pendidikan bagi anak-anaknya (Handayani, C.S., \& Novianto, 2004).

Adanya konstruksi sosial yang diciptakan oleh masyarakat dan masuknya perempuan yang berstatus menikah ke dalam pekerjaan di sektor publik menimbulkan persoalan tersendiri bagi perempuan, terutama mengenai bagaimana mereka mengatur antara pekerjaan domestik dan publik mereka. Demikian juga yang dialami buruh perempuan peternakan ayam petelur PT Rehobat yang berstatus menikah, di mana mereka harus bisa membagi waktunya anatara peran dalam keluarga, dalam bekerja, dan dalam lingkungan rumah.

Para buruh perempuan peternakan ayam petelur PT Rehobat, memanfaatkan waktu sebelum bekerja dan setelah pulang kerja untuk menjalankan perannya sebagai ibu rumah tangga. Hal ini selaras dengan apa yang dikatakan oleh RAW (32 tahun) pada salah satu wawancara yang dilakukan pada Senin, 18 Januari 2021, dirinya mengungkapkan:

"Kegiatan sebelum kerja ya bangun pagi, cari dan beli bahan-bahan untuk dimasak, kemudian memasak, mengurus anak, kemudian kalau masih ada waktu nyapu bersih-bersih, kemudian berangkat kerja. Kalau setelah pulang kerja, njemput anak dari rumah nenek nya, kemudian membantu persiapan anak untuk madarasah, kemudian mengantar anak ke TPQ, pulang, bersih-bersih, istirahat, jam 5 menjemput anak pulang TPQ, kemudian nanti njemur baju (kalau ada cucian), mengosok pakai juga, kemudian nonton TV nonton ikatan Cinta."

Istri yang bertugas mengelola keuangan keluarga, disebut dengan istilah montho-montho. Seperti yang dijelaskan oleh penelitian Budi Gautama Siregar, seorang ibu dalam rumah tangga mempunyai peranan yang sangat besar dalam mewujudkan keluarga bahagia, penuh kehangatan dan juga kasih sayang. Setiap keluarga mempunyai strategi keuangannya masing-masing dalam rangka mempertahankan kelangsungan hidup anggota keluarganya dan kebanyaakan keuangan keluarga diatur sepenuhnya oleh ibu rumah tangga, suami akan menyerahkan sekuruh penghasilannya kepada istri untuk dikelola (Setiowati, 2016).

Hal ini seperti yang diungkapkan oleh I (43 tahun), pada salah satu kesempatan wawancara yang mengungkapkan sebagai berikut:

"Pengelolaan keuangan saya sendiri yang melakukan. Gaji saya dan gaji suami digabungkan, saya yang bawa dan saya yang ngecakke (mengelola) untuk kebutuhan keluarga. Tapi biasanya nanti suami saya beri 300 ribu untuk kepentingannya sendiri. Tidak ada pembukuan atau 
anggaran khusus, kebutuhannya mengalir saja karena sudah terbiasa. Gaji suami dan gaji saya digunakan untuk membeli sayur, lauk pauk untuk makan sehari-hari, buat beli sabun, detergen, sunlight, intinya yang awet-awet itu, dan untuk membayar pajak, beli bensin, kebutuhan lain, untuk nyumbang, tilik bayi, besuk orang saki dan keutuhan tak terduga lainnya. Nanti syukursyukur kalau dalam sebulan bisa sisa, sisanya ditabung."

Sebagai buruh perempuan peternakan ayam petelur PT Rehobat, dalam bekerja mereka memiliki peran sebagai pekerja yang ditempatkan pada posisi operator kandang. Adapun tugas operator kandang adalah memberi makan dan minum ayam berikut obat atau vitamin serta vaksin sesuai jadwal yang ditetatapkan, menjaga kebersihan kandang dari saat kandang masih kosong hingga pasca panen dan memonitor kesehatan ayam (Reza, 2017).

Adapun urutan kerja buruh perempuan yang menempati posisi operator kandang peternakan ayam petelur PT Rehobat yang sehari-hari dikerjakan para buruh perempuan dalam bekerja disajikan pada Tabel 1 .

Tabel 1.

Urutan Kerja Operator Kandang Peternakan Ayam Petelur PT Rehobat

\begin{tabular}{|c|c|}
\hline JAM & KEGIATAN \\
\hline \multirow{5}{*}{$\begin{array}{l}07.00- \\
08.00\end{array}$} & Sanitas tangan dan kaki \\
\hline & Cek air minum \\
\hline & Ambil ayam mati dari cages \\
\hline & Ngorek (meratakan) pakan \\
\hline & Pemberian pakan pagi \\
\hline \multirow{3}{*}{$\begin{array}{l}08.00- \\
09.00\end{array}$} & Selesi eggtray (wadah telur) \\
\hline & Membersihkan lingkungan kandang \\
\hline & Ngorek (meratakan) pakan \\
\hline \multicolumn{2}{|r|}{ Pengambilan telur } \\
\hline \multirow{5}{*}{$\begin{array}{l}11.00 \\
12.00\end{array}$} & Pembersihan telur yang kotor \\
\hline & Pengelompokan telur normal dan abnormal \\
\hline & Membersihkan kandang bagian dalam \\
\hline & Cek dan ambil ayam mati dari cages \\
\hline & Ngorek (meratakan) pakan \\
\hline \multicolumn{2}{|c|}{$\begin{array}{l}12.00 \text { - Istirahat } \\
13.00\end{array}$} \\
\hline \multirow{3}{*}{$\begin{array}{l}13.00- \\
14.00\end{array}$} & Pengambilan telur \\
\hline & Ngorek (meratakan) pakan \\
\hline & Pemberian pakan kedua \\
\hline \multirow{4}{*}{$\begin{array}{l}14.00- \\
15.00\end{array}$} & Ambil brojolan (telur yang mungkin tersisa) \\
\hline & Membersihkan bagian dalam kandang \\
\hline & Ngorek (meratakan) pakan \\
\hline & Mengisi recording \\
\hline 15.00 & Pulang \\
\hline
\end{tabular}

Salah satu buruh perempuan peternakan ayam petelur PT Rehobat, A (52 Tahun) memberikan keterangan tambahan terkait dengan kira-kira jumlah telur yang diambil dan kirakira pakan yang diberikan kepada ayam sebagai berikut: 
"Kalau untuk minum ayam itu sudah otomatis, ada pralon-pralonnya, ayam nya langsung bisa minum sendiri dari pralon-pralonnya itu, nanti saya tinggal mengecek apakah airnya nyala atau tidak. Kalau untuk telur yang diambil sekitar 17 iket lebih 3 eggtry, kalau satu iket itu jumlahnya 240 butir telur. Kalau dijumlah berarti sekitar 4 ribuan telur dalam satu hari. Untuk pakan ayam yang diberikan kepada ayam dalam satu hari sekitar $550 \mathrm{~kg}$, berarti sekitar 11 karung, diberikan 2 kali, pagi dan juga sore."

Peran-peran perempuan di dalam rumah sebagai ibu rumah tangga dan di luar rumah sebagai buruh perempuan bergaji yang telah diuraikan menunjukan adanya sistem ganda. Menurut Walby, teori sistem ganda menganggap bahwa patriarki dan kapitalisme memiliki kesalinghubungan yang sangatlah dekat dan bersifat simbiotik. Ia mengutarakan bahwa patriarki menyediakan sitem kontrol, hukum, dan aturan, sementara kapitalisme menyediakan sistem ekonomi dalam memenuhi keuntungan. Sistem yang ada dalam kuasa patriarki dianggap memberikan kontribusi yang besar bagi peran dan beban kerja ganda yang dilimpahkan oleh para kaum buruh perempuan (Walby, 2014).

Hal tersebut ditunjukan dengan meskipun sudah bekerja para buruh perempuan yang bekerja di PT Rehobat ini dibebani dengan pekerjaan domestik di dalam rumah yang merupakan hasil dari kuasa patriarki. Mereka bekerja menjadi buruh perempuan dan masuk ke ranah kapitalisme agar mendapatkan gaji dan digunakan untuk memenuhi kebutuhan keluarga. Adapun kuasa patriarki juga muncul dalam lingkungan kerja buruh perempuan PT Rehobat, di mana bekerja sebagai buruh pengurus ayam atau disebut dengan operator kandang merupakan pekerjaan yang cocok untuk perempuan karena dianggap memiliki tingkat kesabaran dan ketekunan. Peternakan ayam petelur membutuhkan buruh perempuan karena pekerjaan ini merawat mahluk hidup yakni ayam, sehingga perempuan dianggap lebih bisa merawat mahluk hidup dengan baik.

Selain bekerja di luar rumah, buruh perempuan peternakan ayam petelur PT Rehobat hidup di tengah-tengah masyarakat dan menjadi anggota Rukun Tetangga (RT) maupun Rukun Warga (RW). Berdasarkan hal tersebut maka mereka mengikuti kegiatan yang sifatnya rutin maupun tidak rutin.

Kegiatan-kegiatan yang sifatnya rutin biasanya diikat oleh lembaga formal yang didasari oleh kedekatan letak rumah dan beranggotaka perempuan-perempuan yang sudah dewasa, utamanya sudah menikah, seperti Pemberdayaan Kesejahteraan Keluarga (PKK) dan Dasa Wisma (Dawis). PKK berasal dari organisasi yang mewadahi perempuan untuk mendidik, membina dan membangun keluarga di bidang mental, spiritual dan fisik material, serta mutu sandang, pangan, papan, kesehatan dan lingkungan hidup.

R (46 Tahun) sebagai anggota RT menjelaskan bahwa dirinya juga mengikuti beberapa kegiatan yang ada di lingkungan rumahnya yang bersifat formal maupun non formal. Ia menjelaskan:

“Yasinan saya ikut setiap hari Jum'at, sama baru-baru ini ibu-ibu RT mengadakan senam setiap hari minggu sore, ya saya ikutjuga, ada juga arisan RT setiap satu bulan sekali. Kalau ada orang yang sakitjuga ikut besuk. Ya tetep ikut guyup rukun di masyarakat walupun kerja, toh biasanya kalau ada guyup ruun itu juga dilakukan sore hari ya jadi saya bisa ikut."

Begitu pula dengan M (22 Tahun), buruh perempuan peternakan ayam petelur PT Rehobat yang juga berpartisipasi di beberapa kegiatan lingkungannya, dari yang bersifat rutin maupun insidental. Dirinya mengungkapkan bahwa:

"Ada arisan RT, sama senam setiap sabtu sore, kalau PKK saya tidak ikut. Tapi ikut posyandu anak itu dulu waktu anak saya kecil sampai 3 tahun itu masih ikut posyandu. Besuk kalau ada yang sakit. Takziyah sekalian tahlil kalau ada yang meninggal. Kalau ada yang sunatan atau mantu, nanti rewang juga sama kondangan, kadang kalau suadara dekat juga diajak mbesan". 
Tidak jarang pula buruh perempuan peternakan ayam petelur PT Rehobat yang menempati posisi cukup penting, misalnya berperan sebagai perwakilan kader PKK RW di Kecamatan, bendahara arisan RT dan bendahara kegiatan senam ibu-ibu RT, seperti Fahmidah. Pada salah satu wawancara yang dilakukan SF mengutarakan:

"Saya salah satu perwakilan kader PKK RW, kegiatanya rapat-rapat di kecamatan, mengikuti sosialiasi dan program PKK lainnya. Sempat jadi bendahara ke dua diarisan RT dan sampai sekarang masih dipercaya juga menjadi bendahara di kegiatan senam setiap minggu sore."

Berdasarkan pernyataan-pernyataan dari informan melalui wawancara, pada dasarnya walaupun perempuan bekerja dari pagi hingga sore hari mereka tetap bisa membagi waktunya untuk mejalankan peran lainnya. Sebelum berangkat mereka melakukan tugas rumah tangga terlebih dahulu kemudian setelah peran itu selesai mereka kemudian berangkat kerja, serta dalam beberapa kesempatan mereka melakukan perannya sebagai anggota masyarakat.

Dengan bekerja di luar rumah bersama dengan laki-laki, perempuan dapat "merebut kembali transendensinya". Perempuan akan "secara konkret menegaskan statusnya sebagai subjek, sebagai seseorang yang secara aktif menentukan arah nasibnya (Tong, 2006). Beban kerja ganda (double burden) adalah beban pekerjaan yang diterima salah satu jenis kelamin lebih banyak dibandingkan jenis kelamin lainnya. Peran perempuan di dalam rumah seringkali dipandang permanen. Akibatnya, ketika perempuan turut bekerja di luar rumah, ia masih dibebani tanggung jawab atas kegiatan di dalam rumah.

Michelle et al (dalam Hidayati, 2015) menyatakan bahwa peran ganda disebutkan dengan konsep dualisme kultural, yakni adanya konsep ranah domestik (domestic sphere) dan ranah publik (public sphere). Beban ganda adalah partisipasi perempuan menyangkut peran tradisi dan transisi. Peran tradisi atau domestik mencakup peran perempuan sebagai istri, ibu dan pengelola rumah tangga. Sementara peran transisi meliputi pengertian perempuan sebagai tenaga kerja, anggota masyarakat dan manusia pembangunan. Pada peran transisi perempuan sebagai tenaga kerja turut aktif dalam kegiatan ekonomis (mencari nafkah) di berbagai kegiatan sesuai dengan ketrampilan dan pendidikan yang dimiliki serta lapangan pekerjaan yang tersedia.

Hidayati (2015) lebih jauh menyatakan bahwa beban ganda kaum perempuan terimplikasi pada: (1) peran kerja sebagai ibu rumah tangga (mencerminkan femininine role), meski tidak langsung menghasilkan pendapatan, secara produktif bekerja mendukung kaum pria (kepala keluarga) untuk mencari penghasilan (uang); dan (2) berperan sebagai pencari nafkah (tambahan ataupun utama).

\section{Konstruksi sosial terhadap peran ganda buruh perempuan peternakan ayam petelur PT Rehobat}

Berdasarkan hasil penelitian, terjadi konstruksi sosial oleh para perempuan terhadap pilihan menjadi buruh perempuan di peternakan ayam petelur PT Rehobat. Konstruksi sosial menurut Berger dalam Syafitri (2017) adalah pemahaman bahwa kenyataan merupakan hasil produksi dari manusia itu sendiri yang dibangun secara sosial sehingga kenyataan-kenyataan dan pengetahuan yang dibentuk melalui interaksi adalah dua kunci yang saling berkaitan untuk memiliki suatu pemahaman terhadap suatu objek tertentu

Dua kunci penting yang saling berkaitan untuk memiliki suatu pemahaman terhadap suatu objek tertentu dalam masyarakat tersebut juga dikemukakan oleh Thomas Luckman dalam Gracia (2015) bahwa:

"To Luckmann, either knowledge or what we human being define as reality, are determined socially. According to the author, the interactions are the foundation of the social and have an intermittent character, but are essentially permanent. They allow to guide the interactions of subjects with the other. "The order is the result of the human activity and it is only possible while human activity continues producting." 
Proses dialektika dalam teori konstruksi sosial menurut Berger dan Luckmann terjadi akibat adanya tarik menarik antara kenyataan obyektif dimaknai dengan sikap individu dengan berbagai nilai yang dipegang menunjukkan identitasnya di lembaga sosial dimana dirinya menjadi anggotanya (Karman, 2015). Berger dan Luckmann membagi proses dialektika menjadi tiga bagian, yaitu: eksternalisasi, objektivasi, dan internalisasi (Syafitri, 2017).

Berikut penjelasan mengenai proses dialektika konstruksi sosial yang dikemukakan oleh Berger dan Luckmann yaitu eksternalisasi, objektivasi, dan internalisasi yang terjadi pada para perempuan khusunya yang sudah bekerluarga yang kemudian memutuskan untuk menjadi buruh perempuan peternakan ayam PT Rehobat.

Pertama, proses eksternalisasi, merupakan proses penyesuaian diri dengan dunia sosiokultural sebagai produk manusia dan ekspresi individu dalam kehidupan nyata. Individu-individu dalam proses eksternalisasi mencurahkan ekspresinya sebagaiman peran yang mereka miliki (Berger dalam Karman, 2015). Hasil observasi dan wawancara menunjukan, dalam kesehariannya para informan yang merupakan seorang perempuan yang telah berkeluarga dan memutuskan untuk menjadi buruh perempuan di peternakan ayam petelur PT Rehobat menunjukan di hadapan masyarakat melalui penampilan yang sederhana. Mereka juga menampilkan gaya hidup yang sederhana tanpa berfoya-foya, terbukti dari penghasilan mereka digunakan untuk memenuhi kebutuhan keluarga. Di lingkungan masyarakat pun para buruh perempuan yang bekerja di peternakan ayam petelur PT Rehobat tetap ikut berpartisipasi dalam kegiatan-kegiatan yang ada. Seperti contoh ikut dalam kegiatan senam bersama seperti yang dilakukan oleh informan berinisial RAW, K, N, F dan K. Selain itu informan yang bernama N, F, dan SF, mereka merupakan kader PKK (Pemberdayaan Kesejahteraan Keluarga) di desa masingmasing. Sedangkan seluruh informan buruh perempuan yang bekerja peternakan ayam petelur PT Rehobat, masing-masing ikut terlibat aktif dalam kegiatan masyarakat di daerah masingmasing seperti yasinan setiap hari Jum'at, tahlilan ketika ada orang yang meninggal, kumpulan ibu-ibu di RT (Rukun Tetangga) masing-masing setiap satu bulan sekali, serta besuk ketika ada orang yang sakit.

Kedua, proses objektivasi, terjadi ketika individu mentransmisikan dan membagikan hasil pemahaman yang diperoleh oleh individu tersebut ke orang lain (Berger dalam (Karman, 2015). Dalam proses objektivasi juga terdapat fase penolakan dengan membandingkan antara pengetahuan awal yang diperoleh dan dimiliki dengan kenyataan yang ada dalam masyarakat yang kemudian melahirkan pemahaman tersebut kepada orang lain. Perempuan yang sudah berkeluarga sebelum memutuskan untuk menjadi buruh perempuan di peternakan ayam petelur PT Rehobat telah memiliki pengetahuan awal tentang pekerjaan yang dilakukan yang diperoleh dari buruh perempuan di peternakan ayam petelur PT. Rehobat yang telah bekerja di sana terlebih dahulu dan melalui pelatihan yang dilakukan kepada calon buruh perempuan. Dari pengetahuan awal tersebut membuat mereka berpandangan bahwa menjadi buruh perempuan di peternakan ayam petelur PT Rehobat cukup mudah dan menjanjikan dibandingkan dengan pekerjaan-pekerjaan yang sebelumnya telah mereka kerjakan. Untuk bekerja menjadi buruh perempuan di peternakan ayam petelur PT Rehobat, syarat pendidikan formal tidak ada ketentuan khusus, sehingga para perempuan yang merupakan lulusan SD, SMP, SMA, atau jenjang pendidikan lainnya memiliki kesempatan yang sama untuk menjadi buruh perempuan di peternakan ayam petelur PT Rehobat. Hal ini dibuktikan, dari 10 informan utama buruh perempuan di peternakan ayam petelur PT. Rehobat, satu di antaranya lulusan SD, tujuh diantaranya lulusan SMP, dan dua diantaranya lulusan SMA. Berdasarkan aspek ekonomi, alasan mereka memutuskan untuk bekerja adalah untuk membantu suami mendapatkan penghasilan. Penghasilan tersebut digunakan memenuhi kebutuhan ekonomi keluarga. Hal ini dikarenakan, berdasarkan penuturan mereka jika hanya suami saja yang bekerja, maka penghasilannya tidak cukup digunakan untuk mencukupi kebutuhan ekonomi keluarga. Gaji para buruh perempuan peternakan ayam petelur PT Rehobat ini menurut mereka cukup tinggi menurut mereka yakni UMR (Upah Minimum Regional) Kabupaten Kendal berjumlah 2,3 juta. Secara keseluruhan, dalam proses objektivasi ini para buruh perempuan peternakan ayam petelur PT. Rehobat dapat dengan baik melakukan tugas mereka sebagai ibu rumah tangga dan sebagai pekerja atau buruh 
perempuan. Pun hal ini tercermin dari semua informan yang mengaku mereka sangat senang sekali bisa bekerja di luar rumah dan dapat membantu perekonomian keluarga meskipun di rumah mereka tetap menjalankan tugas-tugasnya sebagai ibu rumah tangga.

Ketiga, proses internalisasi, merupakan proses di mana seorang individu mengidentifikasi diri sendiri dengan lembaga sosial individu tersebut tergabung sebagai anggotanya (Bungin dalam (Diniati, 2018). Diniati mengatakan bahwa proses internalisasi dapat terjadi apabila seorang individu berhasil melewati fase penolakan hingga memasuki fase penerimaan. Para perempuan yang sudah berkeluarga yang kemudian memutuskan untuk bekerja sebagai buruh perempuan peternakan ayam petelur PT Rehobat yang berhasil melakukan adaptasi, maka lama kelamaan akan mengakui, menerima dan mengekspresikan dirinya sebagai seseorang yang memiliki peran ganda sebagai ibu rumah tangga dan juga sebagai pekerja. Informan berinisial RAW, merasa bahwa ia sangat paham mengenai tugas seorang suami dan tugas seorang istri. Menurutnya, tugas utama seorang suami adalah bekerja di luar rumah untuk menafkahi keluarganya, sedangkan tugas seorang istri adalah mengerjakan pekerjaan rumah tangga. Akan tetapi karena kebutuhan ekonomi yang mendesak dan keinginan untuk bekerja serta memperbaiki kualitas hidup, ia yang juga merupakan seorang istri kemudian memutuskan untuk bekerja di luar rumah. Meskipun begitu, ia mengaku masih bisa menjalankan pekerjaan rumah tangga pada saat sebelum berangkat kerja, setelah pulang kerja dan saat libur, mengingat bekerja sebagai buruh di peternakan ayam petelur PT Rehobat ini memiliki jam kerja yang pasti yakni berangkat pada pukul 7 pagi dan pulang pada pukul 3 sore, serta libur setiap 4 hari sekali. Hal tersebut juga senada oleh sebagian besar informan lainnya bahwa meskipun mereka bekerja di luar rumah sebagai buruh perempuan peternakan ayam petelur PT Rehobat, mereka menerima, melakukan dan meyakini bahwa mereka juga seorang ibu rumah tangga yang harus melakukan tugasnya sebagai seorang istri ketika di rumah. Selain melakukan tugasnya sebagai seorang istri ketika di rumah, mereka juga ikut berpatisipasi aktif dalam kegiatan-kegiatan yang ada di masyarakat sekitar. Informan berinisial $\mathrm{M}$ menuturkan, bahwasanya para buruh perempuan peternakan ayam petelur PT Rehobat ini juga mempunyai sebuah perkumpulan. Perkumpulan ini melakukan arisan yang kemudian uang arisan ini digunakan untuk makan-makan di rumah orang yang memperolah uang arisan ini. Sistem pemerolehan uang arisan ini adalah dengan dikocok atau dengan diundi. Bahkan terdapat pula kaos seragam yang dibuat. Perkumpulan ini bertujuan untuk kesenangan dan mempererat tali persaudaraan antar buruh perempuan peternakan ayam petelur PT Rehobat. Hal tersebut menunjukan bahwa mereka menerima dan bahkan menikmati bahwa mereka adalah perempuan yang sudah berkeluarga yang kemudian memutuskan untuk bekerja sebagai buruh perempuan peternakan ayam petelur PT Rehobat dengan melakukan dan menjalakan peran tanggung jawab yang mereka miliki.

Penjabaran di atas menggambarkan konstruksi sosial para perempuan yang sudah berkeluarga yang kemudian memutuskan untuk bekerja sebagai buruh perempuan peternakan ayam petelur PT Rehobat, di mana ketika mereka memutuskan hal tersebut otomatis mereka memiliki peran ganda dan beban kerja ganda. Peran dan beban kerja ganda yang mereka miliki adalah sebagai seorang ibu rumah tangga dengan segala macam tugasnya di rumah dan sebagai seorang pekerja dengan segala macam aktivitas kerjanya. Hal ini dapat digambarkan melalui tiga proses berkesinambungan yaitu eksternalisasi, objektivasi dan internalisasi dialami oleh masingmasing informan. Ketiga proses tersebut merupakan proses dialektika sesuai dengan teori Konstruksi Sosial yang dikemukakan oleh Peter L. Berger dan Thomas Luckmann.

Adapun model konstruksi sosial terhadap perempuan yang sudah berkeluarga terhadap pilihannnya menjadi buruh perempuan sehingga memiliki peran dan beban ganda pada buruh perempuan peternakan ayam petelur PT Rehobat sesuai dengan proses dialektika yang terdiri dari proses eksternalisasi, objektivasi, internalisasi dalam teori Konstruksi Sosial yang dikemukakan oleh Peter L. Berger dan Thomas Luckmann disajikan pada Gambar I. 


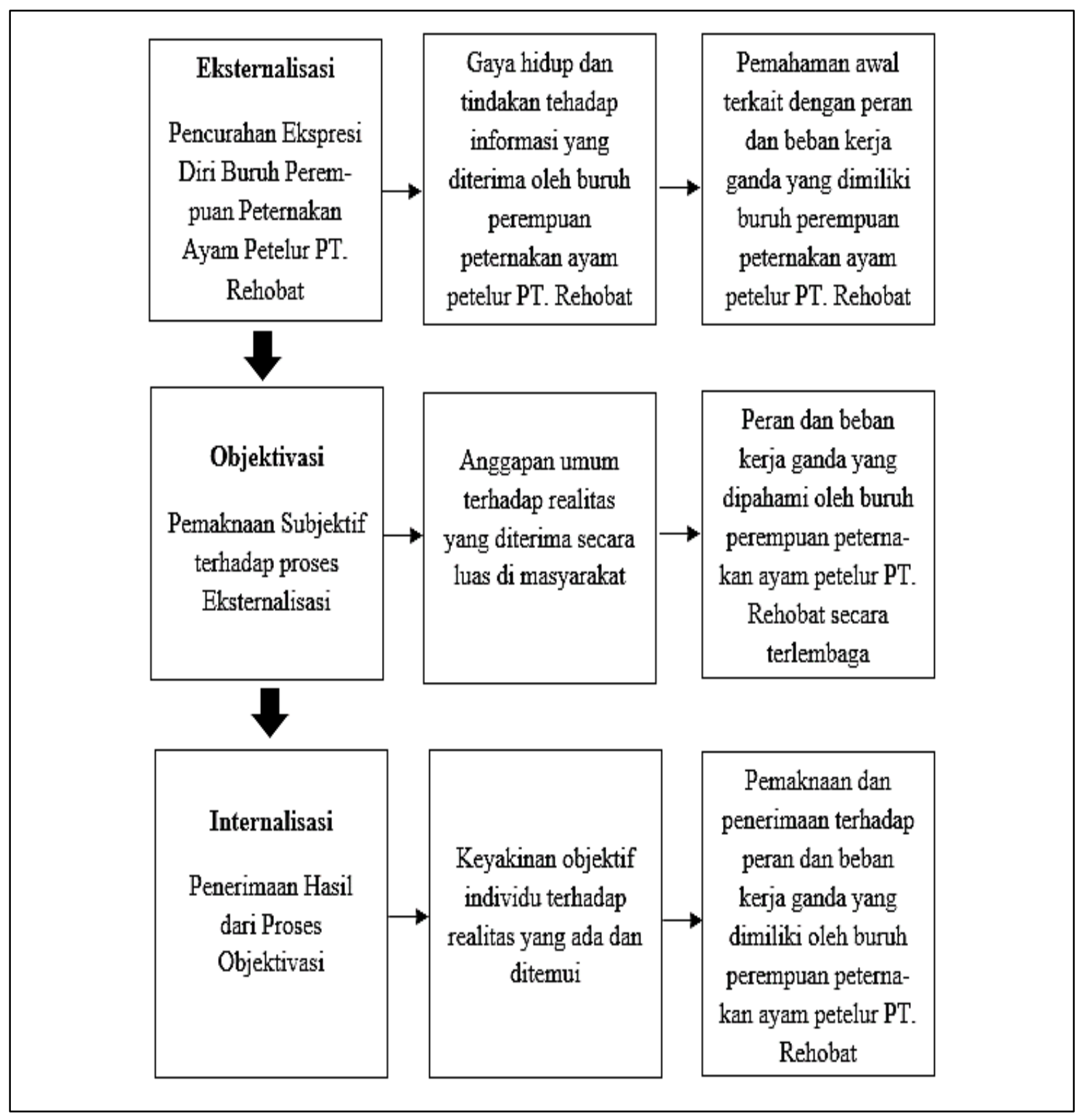

Gambar 1. Model Konstruksi Sosial terhadap Peran Ganda Buruh Perempuan

Peternakan Ayam Petelur PT Rehobat

Sumber: Diolah dari hasil penelitian

Berdasarkan uraian mengenai peran dan beban ganda buruh perempuan yang dialami oleh para buruh perempuan peternakan ayam petelur PT Rehobat yang sudah berkeluarga, maka peneliti menganalisis bahwasanya terdapat dampak yang ditimbulkan jika perempuan yang sudah berkeluarga memutuskan untuk bekerja, Di satu sisi perempuan bekerja di antaranya dapat membantu perekonomian rumah tangga, adanya rasa bangga memiliki karir dan mampu membawa diri di tengah masyarakat, kemampuan untuk menguasai lingkungan, produktivitas dan eksistensi harkat martabat perempuan. Di sisi yang lain, para buruh perempuan tidak memiliki waktu banyak untuk keluarga. Mereka hanya dapat bertemu di waktu pagi hari sebelum berangkat kerja dan sore hari.

Berdasarkan hasil penelitian, para buruh perempuan peternakan ayam petelur PT Rehobat bisa melakoni peran-peran yang dimilikinya, mulai peran dalam keluarga, dalam bekerja, dan dalam lingkungan rumah dengan baik dan sudah menjadi kebiasaan mereka. Hal ini 
dikarenakan mereka telah menjalankan hal tersebut dalam jangka waktu yang lama. Beban kerja ganda yang dialami oleh para buruh perempuan ini tidak terlalu berarti atau tidak terlalu disadari oleh mereka dan menganggap ini semua demi perekonomian keluarga. Dalam posisi ini mereka para buruh perempuan peternakan sekaligus sebagai istri dan ibu, menjalankan fungsi keluarga sebagai fungsi ekonomi, fungsi pengaturan seksual, fungsi reproduksi, fungsi sosialisasi, fungsi afeksi, fungsi penentuan status dan fungsi perlindungan (Syamsuddin, 2018). Sebuah peran yang sebenarnya tak mudah dijalani oleh para perempuan dan sebenarnya memunculkan beban ganda bagi mereka. Beban ganda inilah yang sebenarnya masih menjadi bagian dari situasi yang tidak setara, karena hanya perempuanlah yang menanggungnya, karena laki-laki tidak dibebani hal yang sama, karena peran mereka seolah-olah hanya pada sector public saja.

\section{Simpulan dan Saran}

Berdasarkan pemaparan diatas menunjukkan, bahwa terdapat fenomena beban kerja ganda atau double burden yang telah melekat dan dijalani dengan sepenuh hati oleh pada para buruh perempuan peternakan ayam petelur PT Rehobat. Mereka mempunyai peran ganda yang disebutkan dengan konsep dualisme kultural, yakni adanya konsep ranah domestik (domestic sphere) mencakup peran para buruh perempuan peternakan ayam petelur PT Rehobat di dalam rumah atau keluarga sebagai istri, ibu dan pengelola rumah tangga dan ranah publik (public sphere) mencakup para buruh perempuan peternakan ayam petelur PT Rehobat sebagai tenaga kerja di lingkungkan kerja dan anggota di lingkungan masyarakat. Adapun konstruksi sosial para perempuan yang sudah berkeluarga terhadap pilihannnya menjadi buruh perempuan di peternakan ayam petelur PT Rehobat terjadi melalui tiga proses. Tiga proses dalam konstruksi sosial tersebut berupa proses eksternalisasi, objektivasi, dan internalisasi. Ketiga proses tersebut merupakan sebuah proses dialektika yang sesuai dengan teori Konstruksi Sosial Peter L. Berger dan Thomas Luckmann. Perubahan kondisi dari seorang perempuan yang sudah berkeluarga menjadi buruh perempuan di peternakan ayam petelur PT Rehobat melewati berbagai proses hingga menerima keadaan bahwa mereka seorang buruh perempuan di peternakan ayam petelur PT Rehobat yang memiliki peran dan beban kerja ganda sebagai seorang istri, ibu, pekerja dan anggota dalam suatu masyarakat. Peran dan beban kerja ganda ini seolah melanggengkan situasi ketaksetaraan gender, karena hanya dibebankan kepada perempuan saja.

\section{Daftar Rujukan}

Diniati, A. (2018). Konstruksi Sosial Melalui Komunikasi Intrapribadi Mahasiswa Gay di Kota $\begin{array}{llll}\text { Bandung. Jurnal Kajian } & \text { Komunikasi, }\end{array}$ https://doi.org/doi:10.2419/jkk.v6i2.12768

Gracia, M. R. (2015). Reality Construction, Communication and Daily Life- An approach to Thomas Luckmann work. Intercom-RBCC, 38(2), 19-36.

Handayani, C.S., \& Novianto, A. (2004). Kuasa Wanita Jawa. LKiS.

Hidayati, N. (2015). Beban Kerja Ganda Perempuan Bekerja. Jurnal Muwazah, 7(108-109).

Jannah, S.M., \& Lestari, P. (2007). Peran Ganda Perempuan dalam Kehidupan Ekonomi Keluarga (Studi Kasus: Buruh Perempuan Pabrik Kayu PT Albasia Bhumipala Persada, Temanggung, Jawa Tengah). E-Societas, 7(1), 1-5.

Karman. (2015). Konstruksi Realitas Sosial Sebagai Gerakan Pemikiran (Sebuah Telaah Teoritis Terhadap Konstruksi Realita Petter L. Berger. Jurnal Penelitian Dan Pengembangan Komunikasi Dan Informatika, 5(3), 11-23.

Kusuma. (2014). Menimbang Kodrat Perempuan Antara Nilai Budaya dan Kategori Analisis. Reflesi, 13(6), 780.

Kusumawati, Y. (2012). Peran Ganda Perempuan Pemetik Teh. Komunitas: Interantional Journal of Indonesian Society and Culture, 4(2), 157-167.

Lantara, N. F. (2015). The Roles of Woman as Leader and Housewife. Journal of Defense Management, 5(1), 1-5.

Momuat, S. M., Rantung, V. V., Wangke, W. M., \& Ngangi, C. R. (2013). Kontribusi Kerja Wanita 
dalam Keluarga Petani Aren di Desa Rambunan dan Sawangan Sonder. COCOS Jurnal Ilmiah Fakultas Pertanian Universitas Sam Ratulangi Manado, 2(1), 1-16.

Prakoswa, R. H. (2018). Para Perempuan, Ini Posisi Wanita dalam Ekonomi Indonesia.

Relawati, R. (2011). Konsep dan Aplikasi Penelitian Gender. CV Muara Indah.

Reza. (2017). Memuliakan Anak Kandung. Dalam troboslivestock.com

Setiowati, N. E. (2016). Perempuan, Strategi Nafkah dan Akuntansi Rumah Tangga. Jurnal Perbankan Syariah Dan Ekonomi Islam IAIN Syekh Nurjadi Cirebon, 8(1), 290-304.

Supartiningsih. (2003). Peran Ganda Perempuan, Sebuah Analisis Filisofis Kritis. Jurnal Filsafat, $33(1), 42-54$.

Sutopo, H. (2002). Metode Penelitian Kualitatif. Sebelas Maret University.

Syafitri, I. (2017). Konstruksi Sosial AnakJalanan terhadao Rumah Singgah (Studi Konstruksi Sosial di UPTD Kampung Anak Negeri, Surabaya). Skripsi Universitas Airlangga

Syamsuddin, A. (2018). Cahaya Hidup Pengasuhan Keluarga (Fungsionalisme Struktural dan Interaksionisme Simbolik). Wade Group.

Tong, R. P. (2006). Feminist Thought. (Kurniasih, Ed., \& A. P. Prabasmoro, Trans.). Jalasutra.

Walby, S. (2014). Teorisasi Patriarki. (S. O. Pavitrasari, Ed., \& M. K. Prasela, Trans.). Jalasutra. 